\title{
Descripción fenotípica y avances en la obtención de un inmunógeno contra partículas de virus ISA (HPR7b), aisladas desde un salmón del Atlántico de vida libre capturado en el ecosistema Sur-Austral de Chile
}

\author{
Phenotipic description and advances in obtaining an immunogen against ISAV particles \\ (HPR7b) isolated from a free-living Atlantic salmon caught in the Austral Southern \\ ecosystem of Chile
}

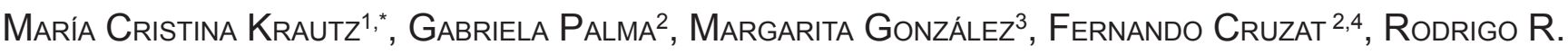 \\ GONZÁLEZ ${ }^{2,4}$ \\ 1 Departamento de Oceanografía, '2Unidad de Biotecnología Marina, ${ }^{3}$ Departamento de Bioquímica Clínica e Inmunología, \\ ${ }^{4}$ Centro FONDAP COPAS SUR-AUSTRAL, Universidad de Concepción, Chile. \\ *E-mail: ckrautz@udec.cl
}

\begin{abstract}
RESUMEN
Se aislaron partículas del virus ISA cepa HPR7b, desde un salmón Atlántico capturado en el ecosistema Sur Austral de Chile. Se describe por primera vez la morfología de este genotipo mediante microscopía electrónica de transmisión. Se estimuló la producción de anticuerpos policlonales contra esta cepa en conejos, observándose respuesta positiva de hemaglutinación a partir del segundo sangrado.
\end{abstract}

El virus ISA (Infectious Salmon Anaemia) ha afectado los cultivos de Salmón del Atlántico (Salmo salar) en Europa y Norteamérica desde 1984. Fue identificado en Chile por primera vez en 1999 (Kibenge et al. 2001a), registrándose además una epizootia entre los años 2007 al 2009, con pérdidas millonarias para la industria acuícola (Kibengue et al. 2009). Esto ha generado la necesidad creciente del desarrollo de herramientas que contribuyan a estudiar su prevalencia en cultivos locales y fauna nativa (González et al. 2011), así como también la producción de moléculas (e.g. anticuerpos) que permitan la detección temprana de brotes de cepas locales del virus. De éstas, el genotipo HPR7b destaca como el más virulento y únicamente presente en Chile (Kibengue et al. 2009). Este trabajo describe fenotípicamente esta cepa y resume los principales avances en la obtención de un inmunógeno capaz de estimular la producción de anticuerpos policlonales en conejos de laboratorio, utilizando partículas virales aisladas desde tejido de salmones muertos e infectados. Las partículas virales fueron obtenidas a partir de tejidos (branquias, hígado y corazón) de un ejemplar infectado de Salmo salar de vida libre capturado en el Canal Puyuhuapi (ver detalles en González et al. 2011), e individuos muertos obtenidos desde cultivos de la región de Los Lagos. Los tejidos fueron homogenizados en tampón TNE ( $\mathrm{pH} 7,2$,
Tris $\mathrm{HCl} 10 \mathrm{mM}$, EDTA $1 \mathrm{mM}, \mathrm{NaCl} 0,1 \mathrm{M}$ ) en presencia de inhibidores de proteasas (PMSF 0,5mM, Leupeptin $100 \mu \mathrm{M}$, Pepstatin A $1 \mu \mathrm{g} \mathrm{mL}^{-1}$ y Aprotinina $\left.10 \mathrm{mg} \mathrm{mL}^{-1}\right), \mathrm{y}$ luego fueron centrifugados a $9700 \mathrm{~g}$ durante $10 \mathrm{~min}$ a $4^{\circ} \mathrm{C}$. Al sobrenadante se le adicionó polietilenglicol $6000(70 \mathrm{~g}$ $\left.\mathrm{L}^{-1}\right)$ y $\mathrm{NaCl}\left(23,2 \mathrm{~g} \mathrm{~L}^{-1}\right)$ para precipitar las partículas virales $\mathrm{y}$ proteínas y luego fue centrifugado a $2150 \mathrm{~g}$ durante 60 minutos a $4^{\circ} \mathrm{C}$, obteniéndose un pellet que fue resuspendido con $300 \mu \mathrm{L}$ de TNE, colocado sobre un gradiente discontinuo de Ficoll 400 a 10 y 25\% y ultracentrifugados (Beckman $\mathrm{L} 7$ rotor $\mathrm{SW} 40)$ a $111.000 \mathrm{~g}$ durante $60 \mathrm{~min}\left(4^{\circ} \mathrm{C}\right)$. Las interfases del gradiente, rotuladas como 2 y 4 de acuerdo al orden de remoción desde el tubo de centrifugado, fueron recolectadas y ultracentrifugadas a $95.000 \mathrm{~g}$ por 45 minutos a $4^{\circ} \mathrm{C}$ (Dannevig et al. 1995 modificado y Kibengue et al. 2000). El pellet obtenido fue resuspendido en $200 \mu \mathrm{L}$ de TNE y almacenado a $-80^{\circ} \mathrm{C}$. La ultracentrifugación permitió la separación de 5 fases reconocibles en todos los tejidos considerados en este estudio, dos de las cuales (fases $2 \mathrm{y}$ 4) mostraron la mayor homogeneidad y concentración de partículas virales, por lo que fueron seleccionadas para detección por reacción en cadena de la polimerasa (PCR), utilizando partidores para el segmento $8 \mathrm{del}$ virus (Wang et al.2006), la inmunización en conejos de laboratorio así como pruebas de hemaglutinación. La cuantificación de partículas 
virales, se realizó mediante Transcripción Reversa (RT) y el ADNc obtenido fue amplificado por PCR en tiempo real utilizando sonda Taqman y partidores para el segmento 8 del virus. Se elaboró una curva de calibración con diluciones seriadas $\left(10^{8}-10^{1}\right.$ copias $\left./ \mu \mathrm{L} \mathrm{ADNc}\right)$, del plásmido $p G E M-T$ easy, que contenía el segmento 8 del virus. Las muestras fueron interpoladas. El PCR mostró, en todas las muestras, detección de material genético proveniente de la infección viral, que según lo reportado previamente por González et al. (2011) para músculo y corazón del mismo individuo de vida libre considerado en este estudio, pertenecían al genotipo chileno de alta infectividad, HPR7b (Kibengue et al. 2009). Las bandas de mayor intensidad observadas (Fig. 1) fueron fase 2 de branquias (individuo infectado con el virus, de vida libre) y fase 4 de corazón (individuo muerto por virus ISA, de cultivo). El análisis cuantitativo de las muestras por RT-PCR mostró alta variabilidad de la concentración de las partículas virales en tejidos y entre individuos (Tabla 1). Las mayores concentraciones fueron observadas en tejido branquial de salmón infectado lo que es consistente con una vía de ingreso para la transmisión horizontal sugerida para este virus (Norwegian Scientific Committee for Food Safety, 2007). En hígado y corazón de individuos muertos se determinaron concentraciones uno y dos órdenes de magnitud menores.

Las partículas virales aisladas fueron adsorbidas a la membrana de eritrocitos de conejos y utilizadas como inmunógeno. Sangre de conejo obtenida en tampón Alsever fue centrifugada a $400 \mathrm{~g}(5 \mathrm{~min})$. Los eritrocitos fueron lavados en el mismo buffer y luego mezclados con partículas virales en proporción 1:100 e incubados durante $1 \mathrm{~h}$. a temperatura ambiente. La interacción entre los eritrocitos y las partículas virales fue comprobada a través de microscopia electrónica de transmisión (MET). Muestras de eritrocitos con virus adsorbidos en su superficie, fueron lavadas en Alsever y fijados en glutaraldehído al 2,5 \% en buffer cacodilato ( $\mathrm{pH} 7,4)$. La postfijación de la muestra se realizó con tetróxido de osmio al $2 \%$ y ferrocianuro de potasio al 1,5\% en buffer cacodilato ( $\mathrm{pH} 7,2)$. La tinción, se realizó con acetato de uranilo y ácido tánico al $1 \%$ y posteriormente, las muestras fueron deshidratadas con un gradiente de alcohol. Finalmente las muestras fueron incluidas en resina EPON, cortadas con el ultramicrótomo MT5000 Sorvall (100 nm de espesor), teñidas con citrato de plomo $0,2 \%$ y fotografiadas en MET a $80 \mathrm{kV}$. Las

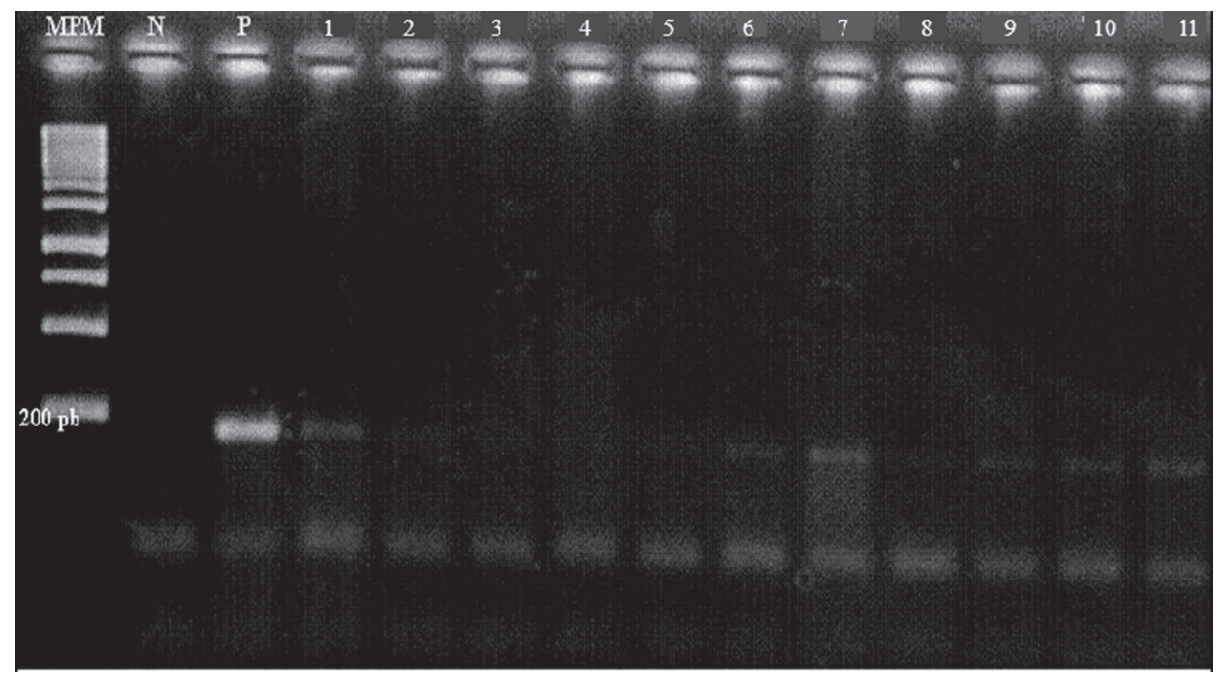

FIGURA 1. Amplificación del segmento 8 del virus ISA desde partículas virales obtenidas por ultracentrifugación. El gel de agarosa, indica la mayor intensidad de bandas obtenidas desde muestras de tejido branquial de Salmo salar infectadas con ISAV. MPM- marcador de peso molecular (1 kb), N- control negativo (agua), P- Positivo certificado (210pb). 1- Fase 2 branquias (infectado) 2- Fase 2 corazón (infectado), 3- Fase 4 hígado (infectado), 4- Fase 4 hígado(infectado, réplica), 5- Fase 2 y 4 branquias (muerto), 6- Fase 4 branquias (infectado), 7 Fase 4 corazón (muerto), 8- Fase 2 hígado (muerto), 9- Fase 2 hígado (muerto), 10- Fase 4 branquias (infectado) y 11- Fase 4 branquias (infectado, réplica).

Figure 1. Amplification of segment 8 of ISA virus from virus particles obtained by ultracentrifugation. The agarose gel shows increased intensity for bands obtained from samples of gill tissue of ISA infected Salmo salar. MPM-molecular weight marker (1 kb), N-negative coP-Positive Certificate (210 pb). 1 - Phase 2 gills (infected) 2 - Phase 2 heart (infected), 3 - Phase 4 liver (infected), 4 - Stage 4 liver (infected, replication), 5 - Phase 2 and 4 gills (dead), 6 - phase 4 gills (infected), 7 - phase 4 heart (dead), 8 - Phase 2 liver (dead), 9 - Phase 2 liver (dead), 10 - phase 4 gills (infected) and 11 - Phase 4 gills (infected replica). 


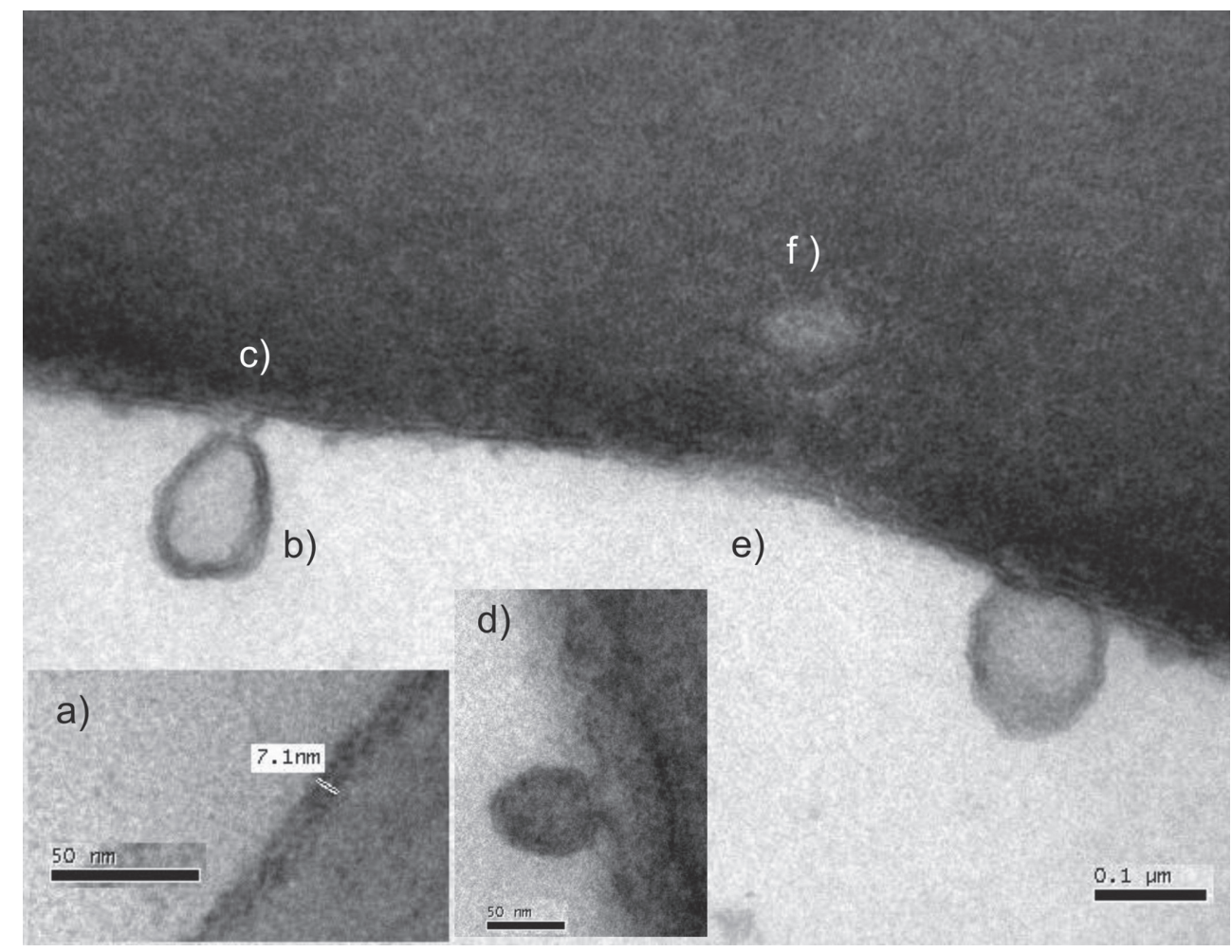

FIGURA 2. Imágenes obtenidas con microscopio electrónico de transmisión que muestran la interacción entre las partículas de virus ISA con eritrocitos de conejo. a) Espesor normal de la membrana de un eritrocito de conejo (control negativo). Se muestran tres estados de la adsorción de partículas virales a las superficies de eritrocitos de conejos: b) partícula viral adsorbida sobre la membrana de eritrocito, se observa envoltura viral. c) engrosamiento de la membrana del eritrocito en el sitio de unión al virus, durante la hemadsorción. d) muestra las proyecciones filamentosas del sistema de anclaje a la membrana del eritrocito d) Invaginación de la membrana celular producto de la endocitosis. e) Partícula viral endocitada por el eritrocito.

FIGURE 2. Images obtained by transmission electron microscopy showing interaction between ISA virus particles and rabbit erythrocytes. a) Normal membrane thickness of rabbit erythrocytes (negative control). Three states are observed for the adsorption of virus particles on the surfaces of rabbit erythrocytes as follow: b) viral particles adsorbed on the erythrocyte membrane, the viral envelope is observed, c) a thickening of the erythrocyte membrane in the virus binding site during the hemadsorption. $\mathrm{d}$ ), shows filamentous projections anchoring system to the erythrocyte membrane. e) Cell membrane invagination produced by endocytosis. f) A viral particle endocyted by the erythrocyte.

micrografías (Fig. 2), mostraron la presencia de partículas virales pleomórficas, cuyo diámetro fluctuó entre $70 \mathrm{y}$ $137 \mathrm{~nm}$. Se encontró una mayor cantidad de partículas sobre los $100 \mathrm{~nm}$ de diámetro, lo que se ajusta a los rangos de tamaño observados por Elliansen et al. (2000, cepa noruega Glesvaer/2/90) y Workhenque et al. (2007, cepa NB ISA 01, genotipo norteamericano, HPR21). No se observó la presencia de viriones de gran tamaño $(>700 \mathrm{~nm})$ como los observados por Dannevig et al. (1995). Los viriones se encontraron en estado libre, adsorbidos en las superficies de la membrana de los eritrocitos de conejo y endocitados. En todos los casos se observó la presencia de una envoltura viral, electrodensa, con proyecciones menores en su superficie similares pero menos abundantes que las descritas por Dannevig et al. (1995). La Fig. 2(c y d) muestra proyecciones filamentosas del sistema de anclaje de la envoltura viral hacia la membrana del eritrocito. En el área de contacto con la superficie celular, se observó el engrosamiento de la membrana del eritrocito alcanzando $53,8 \mathrm{~nm}$, mientras que en el espesor de membrana de eritrocito no expuesto al virus fue de $7 \mathrm{~nm}$ (Fig. 2a). En el estado endocitado (Fig. 2e y f), se observó la formación de una vacuola con una partícula viral en su interior. Posteriormente, para la inmunización de conejos, se inyectaron 3 dosis $(300 \mu \mathrm{L})$ del inmunógeno por vía endovenosa, en intervalos de 3 semanas. Previo al comienzo de la inmunización, se obtuvo un sangrado preinmune. Dos semanas después de cada inmunización se obtuvo un sangrado inmune. De cada sangrado se separó el plasma, que fue centrifugado a $990 \mathrm{~g}(5 \mathrm{~min})$ para eliminar los restos celulares y fue preservado a $-20^{\circ} \mathrm{C}$ para análisis posteriores. Los sueros inmunes obtenidos desde los conejos inmunizados, fueron caracterizados preliminarmente 
mediante reacciones de hemaglutinación. En este análisis fue posible observar una respuesta de hemaglutinación creciente de eritrocitos dentro de las muestras tratadas con los sueros inmunes del primer, segundo y tercer sangrado respectivamente, y ausencia de aglutinación en el suero pre-inmune (Tabla 2). El control negativo del ensayo, compuesto por eritrocitos sin partículas virales, presentó baja hemaglutinación al mezclarlo con el suero inmune del primer sangrado, sugiriendo la existencia de una respuesta inicial de producción de anticuerpos anti-eritrocitos en el suero inmune de los conejos. Los resultados de este trabajo sugieren que es posible la obtención de un inmunógeno a partir de partículas virales obtenidas desde tejido de peces infectados, capaz de estimular la producción de anticuerpos policlonales en conejos de laboratorio. Estos anticuerpos pueden reconocer una mayor diversidad de proteínas y estructuras presentes en la envoltura viral, y enfrentar su potencial variabilidad fenotípica (Kibenge et al. 2000). Este es el primer reporte micrográfico del fenotipo correspondiente al genotipo HPR7b, únicamente reportado en Chile y que fue obtenido de un salmón del Atlántico de vida libre proveniente del ecosistema sur-austral, lo que sugiere fuertemente la existencia de vectores activos en el ecosistema que deben ser considerados en las acciones de manejo y control frente a brotes de la enfermedad (González et al. 2011). El incremento del conocimiento estructural y las variaciones que pueda inducir el ambiente en la morfología de los virus, podría mejorar la efectividad en la formulación de vacunas y mejor comprensión de su interacción con otros componentes del ecosistema marino.

TABLA 1. Concentración tisular de partículas virales (copias $\mu \mathrm{L}^{-1}$ ) obtenidos en Salmo salar infectado y muertos por virus ISA. OIE: Criterio de diagnóstico confirmativo en base a Ct, para Ensayo Taqman (OIE, 2006)

TABLE 1. Tissue concentration of viral particles (copies $\mu \mathrm{L}^{-1}$ ) determined in a free-living Salmo salar infected by ISA virus and Atlantic salmon killed by the same pathogen. OIE: Diagnostic confirmative criteria based in Ct, to Taqman assay (OIE 2006).

\begin{tabular}{cccccc}
\hline Fase & Estado del PEZ & Tejido & Ct Promedio (n=2) & $\begin{array}{c}\text { Concentración } \\
\left(\text { COPIAS DE ViRus } \mathbf{l l}^{-1}\right)\end{array}$ & OIE \\
\hline 2 & Infectado & Branquias & 27,04 & 8130 & Positivo \\
4 & Infectado & Branquias & 26,45 & 12300 & Positivo \\
2 & Muerto & Corazón & 34,37 & 40 & Negativo \\
4 & Muerto & Corazón & 31,49 & 324 & Positivo \\
2 & Muerto & Hígado & 33,30 & 89 & Dudoso \\
4 & Muerto & Hígado & 32,26 & 186 & Positivo \\
2 & Infectado & $\begin{array}{c}\text { Branquias } \\
\text { (réplica) } \\
\text { Branquias } \\
\text { (réplica) }\end{array}$ & $-28,56$ & - & Positivo \\
\hline
\end{tabular}

TABLA 2. Resumen de los resultados observados en las pruebas de hemaglutinación, utilizando los sueros pre-inmunes e inmunes obtenidos en dos conejos (+) 2 a 3 grumos por campo visual, $(++) 4$ a 5 grumos por campo visual, $(+++)$ más de 5 grumos por campo visual.

TABLE 2. Summary of hemagglutination assays using pre immune and immune sera obtained from two immunized rabbits. (+) 2 to 3 lumps by visual field, $(++) 4$ to 5 lumps by visual field, $(+++)$ more than 5 lumps by visual field.

\begin{tabular}{ccccc}
\hline & $\begin{array}{c}\text { Suero } \\
\text { Preinmune }\end{array}$ & Suero Inmune 1 & Suero InMune 2 & Suero InMune 3 \\
\hline Conejo 1 & - & + & -+ & ++ \\
\hline Conejo 2 & - & ++ & +++ & +++ \\
\hline Control negativo & - & -+ & - & - \\
\hline
\end{tabular}




\section{AGRADECIMIENTOS}

A la Dra Pilar Rojas y Facultad de Agronomía de la Universidad de Concepción sede Chillán por facilitar el uso de la ultracentrífuga. Projecto FIC-2008 (GORE, Aysén) "Determination of ISAV in native species and development of cellular line for its propagation and experimentation" (GORE, Aysén) y Programa COPAS Sur Austral (PFB 31/2007).

\section{REFERENCIAS}

DanNeVIG, B.H., FalK, K. \& NAmork, H. 1995. Isolation of the causal virus of infectious salmon anaemia (ISA) in a longterm cell line from Atlantic salmon head kidney Journal of General Virology 76: 1353-1359.

Eliassen, T.M., Frøystad, M.F., Dannevig, B.H., Jankowska, M., Brech, A., Falk, K., Romøren, K. \& GJøen, T. 2000. Initial Events in Infectious Salmon Anemia Virus Infection: Evidence for the Requirement of a low-pH Step. Journal of Viriology : 218-227.

González, R.R., Ruiz, P., Llanos-Rivera, A., Cruzat, F., Silva, J., Astuya, A., Grandón, M., Jara, D. \& Aburto, C. 2011. ISA virus outside the cage: ichthyofauna and other possible reservoirs to be considered for marine biosafety management in the far-southern ecosystems of Chile. Aquaculture 318: 37-42.

Kibenge, S.B., Lyaku, J.R., Rainnie, D. \& Hammell, K.L. 2000. Growth of infectious salmon anaemia virus in CHSE-214 cells and evidence for phenotypic differences between virus strains Journal of General Virology, 81: 143-150.

Kibenge, F.S.B., Gárate, O.N., Johnson, G., Arriagada, R.,KIBENGE, M.J.T. \& WADOWSKA, D. 2001a. Isolation and identification of infectious salmon anaemia virus (ISAV) from Coho salmon in Chile. Diseases of Aquatic Organisms 45: 9-18.

Kibenge, F., Godoy, M., Wang, Y., Kibenge, M., Gherardelli,V., Mansilla, S., Lisperger, A., Jarpa, M., Latorre, G., Avendaño, F., Lara, M., Gallardo, A., 2009. Infectious salmon anaemia virus (ISAV) isolated from the ISA disease outbreaks in Chile diverged from ISAV isolates from Norway around 1996 and was disseminated around 2005, based on surface glycoprotein gene sequences. Journal.of Virology. 6: 88.

Norwegian Scientific Committee For Food Safety, 2007. Which risk factors relating to spread of infectious salmon anaemia (ISA) require development of management strategies? http://www.vkm.no/dav/3eb6ef12f4.pdf, 3p.

Workenhe, S.T., Wadowska, D.W., Wright, G.M., Kibenge, M.J.T. \& Kibenge, F.S.B. 2007. Demonstration of infectious salmon anaemia virus (ISAV) endocytosis in erythrocytes of Atlantic salmon. Virology Journal 4:13.

Recibido: 24.04.12

Aceptado: 13.09.12 